trade union movement with the Labour party, with employers' organisations, the Government and, more briefly, with international bodies.

Valuable as are these studies in removing misconceptions regarding trade unions, the fifth study may prove to be the most important from that point of view. In this study of relations on the job, Planning gives a clear account of the position and functions of the shop steward that can scarcely fail to assist constructive thought on the whole question of organisation at the workshop level and the development of joint consultation, whether from the point of view of production or for other purposes. Moreover, the concluding section on psychological and other factors affecting relations indicates the importance of a number of the problems which the Panel on Human Factors of the Committee on Industrial Productivity is already examining.

For these factual studies, that Committee may well be grateful to Political and Economic Planning; but the last study, of trade unions in post-war Britain, which surveys trade unionism in relation to economic policy, full employment, nationalized industries and other major questions of the day is undoubtedly that which will have the widest appeal. This brilliant but sympathetic analysis should challenge constructive thinking within and without the unions, and indicates where the real psychological obstacles to high productivity and industrial democracy lie. For this study alone Political and Economic Planning has earned the thanks of all who are seeking the economic recovery of Britain, and no better approach could well be made to that essential task of education and the improvement of public relations than this concise and impartial assessment of opportunities, responsibilities and shortcomings.

\section{CLINICAL ENDOCRINOLOGY}

Clinical Endocrinology and Constitutional Medicine By Dr. A. P. Cawadias. Pp. xii $+368+10$ plates. (London: Frederick Muller, Ltd., 1947.) 42s. net.

$\mathrm{T}$ HIS is an interesting and useful book. The author has made an extensive survey of the clinical conditions that can be attributed to malfunctioning of the endocrine organs, and has based his observations upon a reasoned picture of the "physiology and pathology of the neuro-endocrine systems". The introductory part of the book, which deals with this basic information, begins with a discussion of the concept of hormonal action and of the present trend for endocrinology to find its main links in the general field of metabolism. The rest of the introductory section is devoted to a general description of the "neuro-endocrine systems" of which the derivatives of the branchial pouches are part; of the neuro-metabolic systems based upon the gonads and the adrenals; and of those based upon the pituitary and pineal. By "system" Dr. Cawadias does not mean that a given endocrine substance is responsible for a series of changes that are part of a pattern of wider change which is influenced by the whole endocrine system. The term is used to emphasize the point that the endocrine organs work in a system with such neural structures as the hypothalamus, and that the latter in turn may be influenced by psychogenic factors. When he talks, for example, of the thyro-hormone system as being part of the neuro-endocrine system, he has in mind that cortical influences can affect the hypothalamus; the hypothalamus the anterior lobe of the pituitary; and the anterior lobe the thyroid; and that the whole thyroid system can be activated from any of these centres.

After its introductory section the book deals in turn with clinical disorders that relate to the thyroid, parathyroid and thymus group of glands; to those that relate to the gonadal adrenal group ; to those of the pituitary pineal group; and to those of the pancreas liver group. The description of each disorder begins with a brief definition of the condition it discusses, and then surveys its etiology and physio-pathology, its signs and diagnosis, and its treatment.

The book is well written, and contains numerous interesting references to the older literature. References to recent advances in experimental endocrinology are, however, somewhat unnecessarily restricted. The illustrations are reproductions of drawings, and may not be to the taste of all readers.

\section{NATURE CALENDAR}

\section{The Course of Nature}

Through the Year from the Pages of The Times. Pp. 336. (London: Hodder and Stoughton, Ltd., 1948.) 10s. 6 d. net.

" DHROUGH the Year from the Pages of The Times" is the sub-title of "The Course of Nature" by W. Kay Robinson, well known as a sound field naturalist and an able writer, with a pen in the true Gilbert White tradition. He speaks of the changing seasons, the happenings of the passing days and reviews the pageant of the year in two weekly commentaries.

Beginning with "New Year Bird Songs" and the music of the great tit, "who seldom fails to ring his bell before this month is one week old", Mr. Robinson journeys interestingly onwards through the months to finish at Christmastide with the great tit once more trying his voice. On the way the author has much to write about; for example, one of his January notes deals with the "grey squirrel's New Year Celebrations". Commenting on the activity of the grey squirrel during the hardest of weather he goes on to say: "As one passes through the oakwoods one hears, first, a 'huff, huff, huff', followed by the queer sound which, beginning like a jay's harsh screeching, ends like a kitten's mew, and is possibly a love-call, possibly a challenge, or perhaps just means the squirrel is very much annoyed". The reviewer believes this cry to be a love-song, an idea supported by the date of birth of the young, many litters being born in February.

From squirrels to moles, from moles to waxwings, and then to redwings, flits the author's pen, commenting with regard to the last named on their inability to stand prolonged hard weather. "Though they come to us from colder regions to the north, the redwings seem constitutionally less fitted to withstand the rigours of winter than our own thrushes and blackbirds, and once the hedgerows have been stripped of berries they are in a bad way." But to appreciate this excellent survey of Nature through the seasons it must be read chapter by chapter, for it is full of good matter and that whether the month be January or June.
Frances PitT 